A. Chernov, Master in Geophysics E-mail: achernovp@gmail.com, M. Reva, Cand. Sci. (Phys.-Math.), Assoc. Prof., E-mail: mvreva@gmail.com, Taras Shevchenko National University of Kyiv Institute of Geology, 90, Vasylkivska Str., Kyiv, 03022, Ukraine

\title{
INFORMATIVENESS OF THE GPR METHOD ON THE EXAMPLE OF RESULTS FROM EXPERIMENTAL SITE
}

\author{
(Рекомендовано членом редакційної колегії д-ром фріз.-мат. наук, с.н.с. І. М. Корчагіним)
}

In this article the results of Ground penetrating radar (GPR) surveys on experimental site near Institute of Geology of Taras Shevchenko National University of Kyiv (Kyiv, Ukraine) are represented. GPR method has been developed since 1970, but the problem of GPR profiles quality assessment and the best settings for GPR surveys remains controversial. GPR researches on artificially created site were carried out by three radars with $300 \mathrm{MHz}$ and $500 \mathrm{MHz}$ antennas. Assessment of GPR method informativeness was performed according to the analysis of experimental data with the following criteria: correspondence of registered anomalies on GPR profiles to the actual location of the objects; dependence of GPR profiles quality on the central frequency of antenna, step of measurement, settings of survey depth, season of surveying and number of points on vertical scale. Comparative analysis of the GPR investigations quality was carried out with method developed by authors. As a result of experimental data analysis conclusions and practical recommendations, which can be applied for GPR investigations on the territories, with similar geological structure and similar characteristics of objects to experimental site, are pointed out.

Keywords: ground penetrating radar, GPR, GPR profile, dielectric permittivity, electrical resistivity, GPR survey settings, pipes, metal, loam, sand, gravel, void.

Introduction. Ground penetrating radar (GPR) sounding is applied in the practice of engineering and geotechnical studies intensively since the 1970s. Over the past 1520 years GPR method has become quite widespread and today the scope of application is growing steadily.

The terms 'ground penetrating radar (GPR)', 'groundprobing radar', 'sub-surface radar' or 'surface-penetrating radar (SPR)' refer to a range of electromagnetic techniques designed primarily to locate objects buried beneath the earth's surface or located within a visually opaque structure [14].

The essence of GPR shooting is registering electromagnetic waves, which are generated by transmitter and reflected from boundaries between parts of investigated environment with different electrical, dielectric and magnetic properties.

Development of the subsurface radar sounding method for objects and processes identification have begun in the second decade of the last century. Petrovskiy A. was one of the first developers of the GPR technics theory and conducted practical researches of radio wave ray method ("shadow method"), the implementation of which is based on the measurement of high-frequency wave fields, in 1923-1928 years. Since 1930, stepped electromagnetic research method was used as a method for ice thickness evaluation, identification of fresh water and salt deposits [14], for researches in the desert and on rock.

GPR method was intensively developed after World War II, because of the emergence of new problems and production of new radars. The result [3] is essential for theoretical foundations of high-frequency radio wave methods. Modern theoretical and practical aspects of subsurface georadar sounding are described and developed by M. Vladov, D.J. Daniels, A. Petrovskiy, V. Sugak, E. Tomaszewska, M. Finkelshteyn, K. Yankovskiy [1, 3-5, 7-8, 13-15, 16].

Basically, GPR method is similar to the seismic survey, because both methods are based on theory of wave fields - electromagnetic and elastic waves, respectively. Advantage of GPR method is that survey can be carried out without contact with the surface, but for seismic survey contact with the surface is mandatory.

Currently, the scope of GPR method is steadily increasing, as researchers have wide range of GPR equipment and access to technical tools that can be used for investigations in different conditions [10].

The problems, which are solved with GPR can be divided into two groups according to the current geological objective and methods of researching and data processing:
1 - geological, geotechnical and hydrogeological [9, 12] - differentiation of geological layers, mapping of geological structures, determination of groundwater level and thickness of the ice cover;

2 - searching and examination of geological structures and objects of human activity $[13,15]$ - pipelines, cables, waste, archaeological sites and burials, underground cavities (karst cavities, mines, cellars), heterogeneities and defects, which are hidden in the walls and underground structures, discontinuities in the construction of roads and runways.

Application of GPR survey can help to solve any problem of finding objects that differ in their electrical properties from the surroundings [11].

Today experts have a wide range of radar equipment and access to hardware and software, however, the influence of several factors (both methodological and natural) on the quality of resulting profiles is not fully understood and these factors are under discussion nowadays [11].

In this paper, the results of GPR profile quality investigation are represented. Influence of GPR technical parameters and environmental factors on the quality of recorded profiles was investigated. Researches were conducted on specially equipped experimental site for testing of GPR and other near-surface methods near Institute of Geology of Taras Shevchenko National University of Kyiv (Kiev, Ukraine).

Theoretical basics and equipment. GPR method is one of the electromagnetic methods modifications and the main principals of investigations are based on physical characteristics such as: relative dielectric permittivity of the medium $(\varepsilon)$ - physical quantity that describes in how many times the force of interaction between two electric charges in the environment is less than in the vacuum; electrical resistivity $\left(\rho, \mathrm{Ohm}^{*} \mathrm{~m}\right)$ or specific conductivity of the medium $\left(\gamma=1 / \rho, O \mathrm{Oh}^{-1} / \mathrm{m}=\mathrm{S} / \mathrm{m}\right)-$ parameters that characterize the environment's ability to resist or conduct electricity respectively; relative permeability $(\mu)$ - parameter that describes the ability of the medium to concentrate the magnetic field lines of the external magnetic field. The upper part of the geological medium, for which GPR method is applied, is considered to be non-magnetic $(\mu \approx 1)$, so it is clear that in this case the dominant feature of the environment is dielectric permittivity $\varepsilon$.

The value of the dielectric constant influences the speed of propagation of electromagnetic waves $v$, and thus the accuracy and resolution of GPR investigations. The speed of wave propagation is calculated according to the formula: 


$$
v=c / \sqrt{\mu \varepsilon},
$$

where $c=3 \cdot 10^{8} \mathrm{~m} / \mathrm{s}$ - the speed of electromagnetic wave propagation in the vacuum (speed of light)..

Wave reflects from the boundary between two mediums with different dielectric permittivity, comes to receiver and growth of the wave's amplitude is recorded. The depth " $h$ " to the boundary is calculated according to the formula:

$$
h=\frac{1}{2} \sqrt{v^{2} t^{2}-d^{2}}=\frac{1}{2} \sqrt{\frac{c^{2} t^{2}}{\mu \varepsilon}-d^{2}},
$$

where $t$ - period of time (ns) between electromagnetic wave generation and its arrival to the receiver; $d$ - the distance $(\mathrm{m})$ between transmitter and receiver of electromagnetic wave; $\mu$ and $\varepsilon$ - relative magnetic permeability and permittivity of investigated environment. Therefore, formula (2) shows that the depth to the reflector in the case of nonmagnetic environment $(\mu \approx 1)$ primarily depends on the dielectric constant of the medium [11].

For layered environment with different dielectric constant for each layer depth $\mathrm{h}$ to reflector should be calculated according to the formula (2) in which $v$ and $\varepsilon$ are the average speed of electromagnetic wave and average di- electric permittivity of environment above reflector respectively. Average velocity of electromagnetic wave and dielectric permittivity of the environment are connected with geometric parameters of the layer by next ratios:

$$
v=h / \sum\left(h_{i} / v_{i}\right) ; \quad \varepsilon=\left[\sum\left(h_{i} \sqrt{\varepsilon_{i}}\right) / h\right]^{2},
$$

where $h_{i}, v_{i}, \varepsilon_{i}$ - thickness, velocity of electromagnetic wave and dielectric permittivity of layers above reflector respectively. If there is random function of dielectric permittivity variation with depth $(v(z)$ and $\varepsilon(z))$ then ratios (3) should be written as integral ratios:

$$
\mathrm{v}=h / \int_{0}^{h} \frac{d z}{\mathrm{v}(z)} ; \quad \varepsilon=\left[\int_{0}^{h} \sqrt{\varepsilon(z)} d z / h\right]^{2}
$$

GPR survey was carried out with GPRs VIY2-300, VIY3-500, VIY3-300 (fig. 1), which are produced by LLC "Transient technologies". These GPRs are designed for identification of heterogeneity underground in the soil and in rock; for examination of geological structures and human-made constructions.

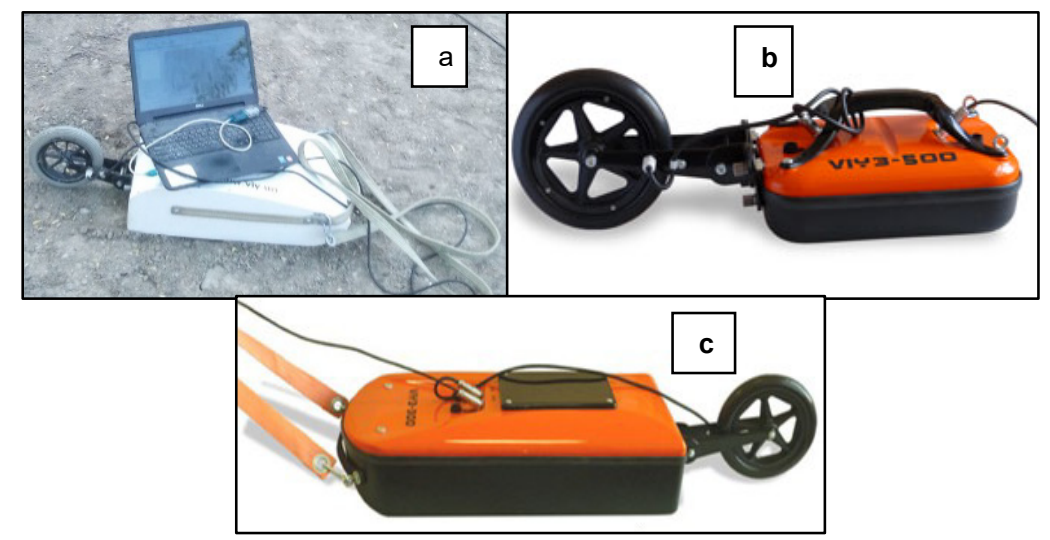

Fig. 1. Appearance of applied GPRs [6]: a - VIY2-300, b - VIY3-500, c - VIY3-300

One of the main advantages of these devices is presence of odometer, which is connected to the GPR and helps to measure distance on the profile very precisely. Devices are connected to the laptop with USB-cable. In these GPRs, transmitter and receiver are in one case, which guarantee reliability and comfortable applying of equipment.

Specifications of GPRs VIY are described in the table 1.

Specifications of applied GPRs

Table 1

\begin{tabular}{|l|c|c|c|}
\hline \multicolumn{1}{|c|}{ Model of GPR } & VIY3-500 & VIY3-300 & VIY2-300 \\
\hline Max sounding depth, $\mathrm{m}$ & 4,0 & $8,0-15,0$ & $8,0-15,0$ \\
\hline Antenna unit, MHz & 500 & 300 & 300 \\
\hline Spatial resolution, meters, (not worse) & 0,18 & 0,3 & 0,3 \\
\hline Dimensions, mm & $311 \times 176 \times 152$ & $610 \times 312 \times 170$ & $311 \times 176 \times 152$ \\
\hline Weight, fk & 3,0 & 10,4 & 13,0 \\
\hline Analogue-to-digital Converter range & 18 & 18 & 10 \\
\hline Dynamic range at least & 135 & 135 & 100 \\
\hline Interface & USB 2.0, Wi-fi & USB 2.0, Wi-fi & RS232 \\
\hline Operating temperature range & \multicolumn{3}{|l}{ Від $-20^{\circ} \mathrm{C}$ до 40 $0^{\circ} \mathrm{C}$} \\
\hline
\end{tabular}

As usual, during GPR survey kinematic, amplitude and frequency electromagnetic wave parameters are recorded:

1) wave arrival time $t$ (in nanoseconds (ns)) - the time period which lasts between moment of electromagnetic wave radiation from transmitter and electromagnetic wave coming to the receiver from the investigated environment;

2) the signal amplitude - the intensity of fluctuations of electromagnetic waves (measured in $\mathrm{dB}$ );
3) frequency of signal - number of periods of waves oscillation per unit of time (as usual for GPRs in megahertz (MHz)).

For researches, which are described in this paper, primarily wave arrival time and amplitude of the signal were used for investigations and conclusions.

Original GPR profiles contain noises before processing (fig. 2a). Processing was done in software "Synchro" and "Planner", produced by LLC "Transient technologies". In 
these programs, several tools were used to improve the quality of GPR profiles:

1) tool "Wavelet filter" that performs convolution of the track with the function of a given period;

2) tool "Background removal" is used to minimize noises from the device and surroundings around the objects. As a result, this tool helps to improve the signal/noise ratio;

3) tool "Gain" is intended for setting the level of signal amplification to obtain more informative and high-quality images of GPR profiles;
4) instrument "Three point correlator" was applied for averaging of signal's amplitude in a certain radius on three tracks (from top to the bottom). Parameters of the instrument are set manually by the operator during the processing of profiles.

Example of GPR profile before and after the initial processing shown on fig. 2.

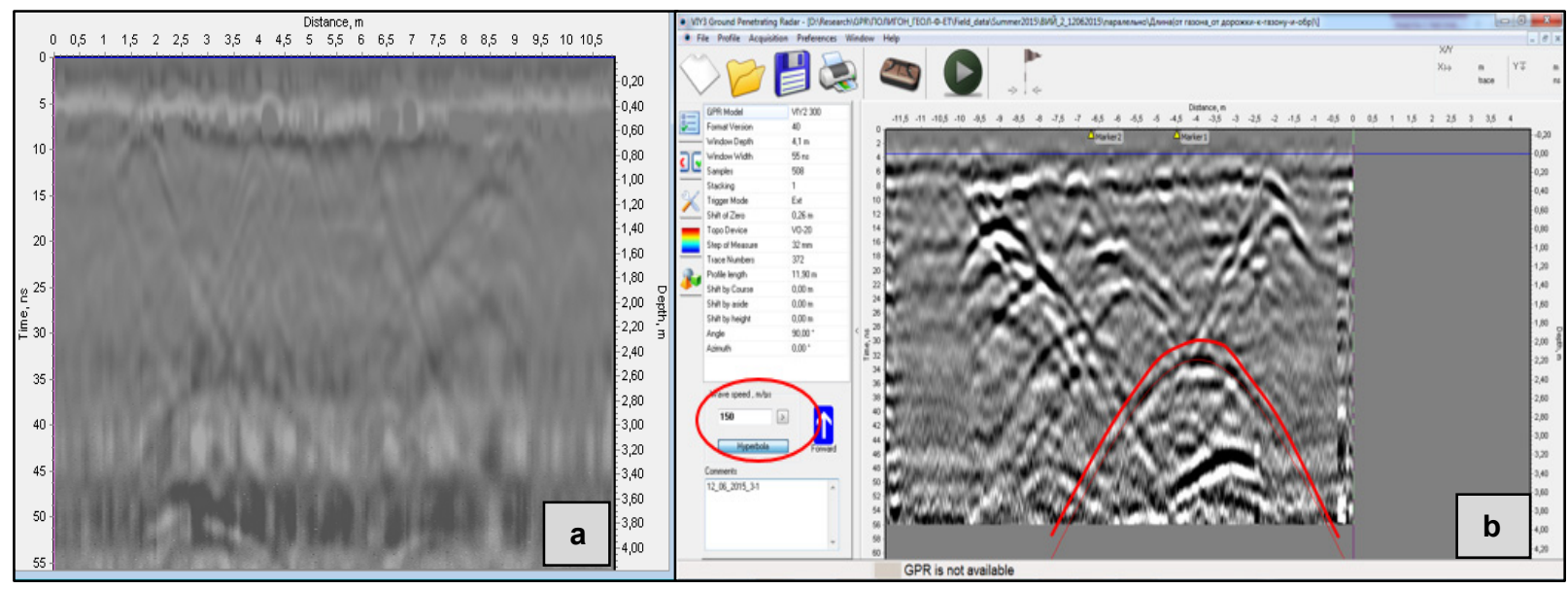

Fig. 2. GPR profile before filtering (a) and after filtering (b); hyperbola is selected with tool "hyperbola" in software "Synchro" (Transient Technologies)

It is necessary to evaluate the speed of propagation velocity of electromagnetic waves to determine the depth to the reflector (formula (2)). Tool "Hyperbola" was used to determine the speed of electromagnetic waves propagation in the environment. It was done by choosing hyperbola that follows the contours of hyperbolic hodograph caused by reflections from a point-like objects (fig. $3 b$ ). This tool helps to determine the speed of electromagnetic waves $v$, and as a result the depth to the reflective object $h$, as hyperbolic equations hodograph is:

$$
t=\frac{\sqrt{(x-d / 2)^{2}+y^{2}+h^{2}}+\sqrt{(x-d / 2)^{2}+y^{2}+h^{2}}}{v},
$$

where $\mathrm{t}$ - period of time (ns) between electromagnetic wave generation and its arrival to the receiver; $x, y$ - coordinates of GPR location; zero is located in the point where projection of the object on the surface is located, $d-$ the distance between transmitter and receiver of electromagnetic wave.

It is mandatory to set "zero-timing" to get precise value of depth to reflective objects and boundaries. "Zero-timing" is the beginning of depth counting, which is connected to the first extremum of signal on GPR tracks. Color and its intensity on GPR profiles represent value of the amplitude in the exact point of GPR profile.

All GPR profiles were processed with the same set of tools and comparison of GPR profiles quality was done.

Experimental site near Research Institute "Institute of Geology" was designed for the educational and experimental researches with GPR and other geophysical methods for near-surface investigations. There are two spots on the site, which are called "Trench" and "Dump-body".

On the fig. 3a there is a plan (top) and cross-section (bottom) of spot "Trench". Surroundings of the pit is represented by loam; trenches' depth is $4 \mathrm{~m}$, length is 7 meters and width is $2.4 \mathrm{~m}$, the pit is filled with sand; there are buried artificial objects on different depth levels (list of objects and their characteristics are given bellow the fig. 1).
GPR survey was done along the spot; the distance between profiles was $0.5 \mathrm{~m}$. On the fig. 1a 5 directions of survey are marked with red lines, length of each was $10.75 \pm 0.15 \mathrm{~m}$.

In order to investigate changes in quality of the results and study the influence of seasons on the quality of the received data, fieldwork within this spot was conducted in different seasons (dates.month.year): 9-12.06.2015, $22.09 .2015,02.12 .2015,27.03 .2016,12.04 .2016$. To investigate informativeness of GPRs with different specifications, research on the spot was conducted with three GPRs: VIY2-300, VIY3-300, VIY3-500 (fig. 2, table 1). Total amount of recorded profiles on the spot "Trench" is 177 profiles for mentioned periods.

Fig. 3b shows a plan (top) and cross-section (bottom) of the spot "Dump-body". Depth of the pit is $4 \mathrm{~m}$, length is 5.8 meters and width is to 4 meters. The design of this spot resembles a dump-body truck that is why it is called "Dump-body". The pit is filled with pebbles of granite. There are 5 metal pipes with a diameter of $10 \mathrm{~cm}$ (marked with black dots on cross-section and with thick black lines on the plan) at different depth levels.

On the spot "Dump-body" researches were performed along 8 directions (marked with horizontal lines with numbers on the plan). The distance between profiles was $0.25 \mathrm{~m}$, and length of profiles is $8 \pm 1,0 \mathrm{~m}$. Experimental work on this spot was also done in different time periods $(9-12.06 .2015,02.12 .2015,12.04 .2016)$ with VIY3-300, VIY3-500 GPRs. Total number of recorded profiles is 58 for the spot "Dump-body".

Results. Example of GPR profiles comparison, which were recorded at the spot "Dump-body" (profile №2) with VIY3-300 $(300 \mathrm{MHz})$ and VIY3-500 $(500 \mathrm{MHz})$ GPRs are shown on fig. 4. On the profiles, which were recorded in spring, hyperboloid anomalies are clearly seen, which are provoked by presence of point-like objects (steel pipes) and tilted anomaly, which is a reflection of electromagnetic wave from metal plane. There is also a hyperboloid anomaly on the depth of $3.6-3.8 \mathrm{~m}$, which shows location of 
metal plane bending. In addition, signals on GPR profiles, which are recorded with $300 \mathrm{MHz}$ antenna are characterized by higher amplitudes, than signal from $500 \mathrm{MHz}$ antennas. On GPR profile, which is recorded in winter, it is harder to identify anomalies from objects than on GPR profiles, which are recorded in other seasons. Such unclear results in winter occurred because of layer of snow between device and earths' surface, which lead to noises on GPR profiles.
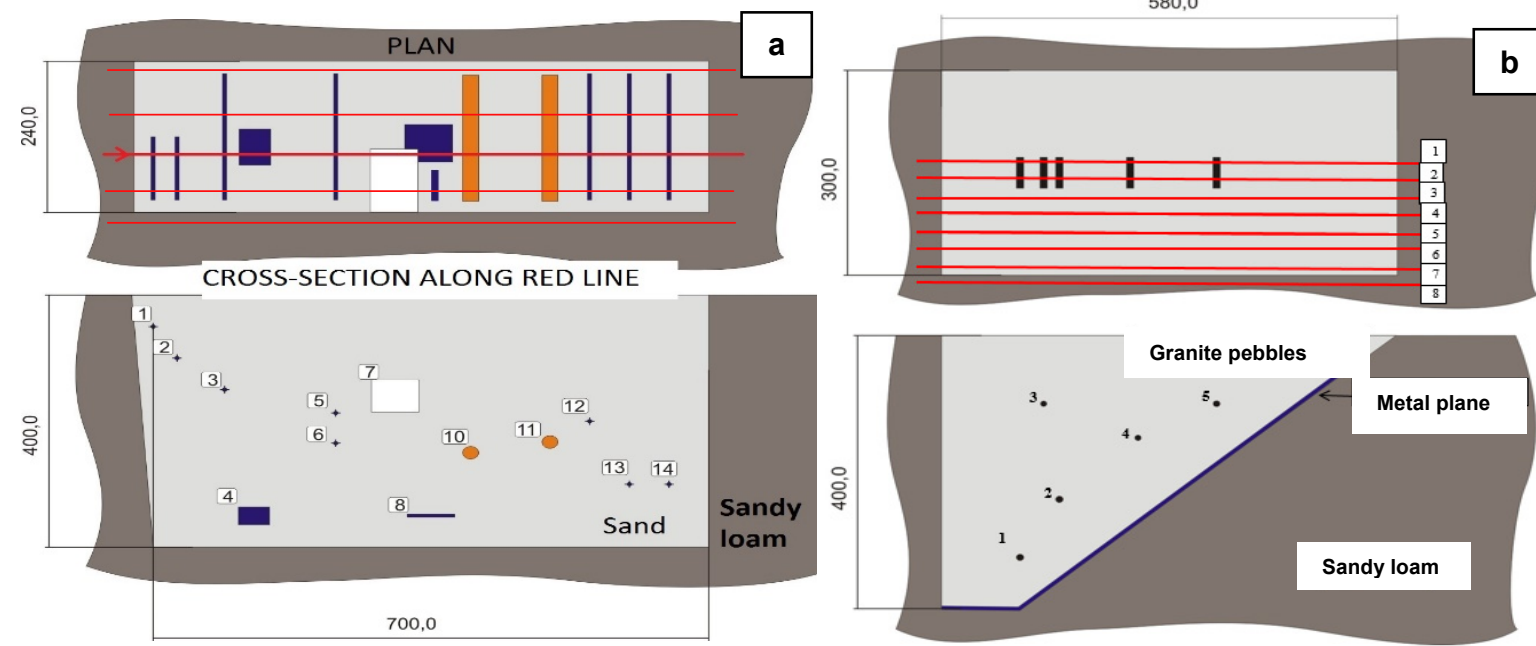

Fig. 3. Spots "Trench" (a) and "Dump-body". On the top,

there are plans of spots with directions of survey and bellow - cross-sections :

a - Objects: 1,2 - steel pipes, diameter $5 \mathrm{~cm}$, length $1 \mathrm{~m} ; 3,13$ - steel pipes diameter $5 \mathrm{~cm}$, length $2 \mathrm{~m}$ with wire inside;

4 - metal box $(0.5 \mathrm{~m} \times 0.8 \mathrm{~m} \times 0.4 \mathrm{~m}$, empty inside); $5,6,12,14$ - steel pipe diameter $5 \mathrm{~cm}$, length $2 \mathrm{~m} ; 7$ - styrofoam $(1 \mathrm{~m} \times 0.5 \mathrm{~m} \times 0.5 \mathrm{~m})$;

8 - metal plane $(0.8 \times 0.8 \mathrm{~m}) ; 10,11$ - plastic pipe diameter $20 \mathrm{~cm}$, length $220 \mathrm{~cm}$; b - Objects: 5 metal pipes (1-5) with a diameter of $10 \mathrm{~cm}$ are marked with black dots on cross-section and with thick black lines on the plan

GPR profiles, which are shown on fig. 5-6 are recorded with VIY3-300 GPR on the $3^{\text {rd }}$ profile on the spot "Trench" with different steps of measurement and with different length of measurement (with different settings of depth). The pictures $4-6$ show that reflections from the most of objects are visible on the profiles. The Best quality of GPR profiles on spot "Trench" is obtained with length of recording $65 \mathrm{~ns}(V=130 \mathrm{~m} / \mathrm{mks}, \varepsilon=5,3, h=4,2 \mathrm{~m})$ and ideal range of measurement steps is from $30.94 \mathrm{~mm}$ to $123 \mathrm{~mm}$.

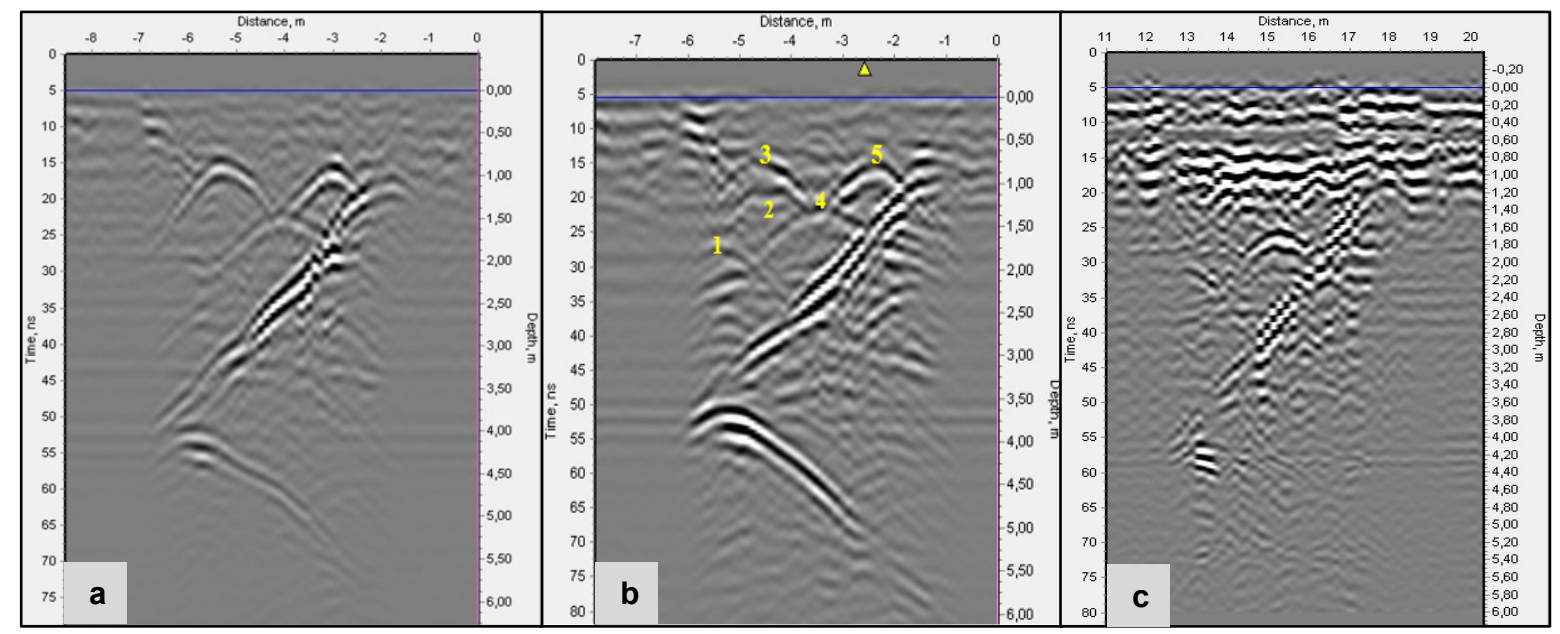

Fig. 4. GPR profiles (№2 on the plan on fig. 1b), recorded on the spot "Dump-body" in different seasons and with different GPRs: a - VIY3-500, September 2015; b - VIY3-300, September 2015 (numbers for anomalies according to numbers for objects on fig. 1b); c-VIY3-500, December 2015

After analysis of other experimental results on the spot "Trench", it was concluded that on GPR profiles, which are recorded with $500 \mathrm{MHz}$ antennas, anomalies from shallow objects (buried on depth to $2 \mathrm{~m}$ ) are localized more precisely than with $300 \mathrm{MHz}$ antennas. Due to higher frequency $(500 \mathrm{MHz})$, there is better resolution on shallow depth, but worse for deeper investigations (deeper than $2 \mathrm{~m}$ ).

As a result of surveying, 235 GPR profiles where recorded with different settings of GPR and in different seasons. Evaluation of quality and informativeness of profiles and their dependence on several settings was investigated. For comparison of profiles 6 parameters were taken into consideration:

1) frequency of antenna;

3) step of measurement;

4) length of GPR trace in ns (depth of investigation);

5) resolution of trace ( "the number of points on vertical axis");

6) Season of the survey.

Comparison was done for GPR profiles with the change of only one parameter, while others were constant. 

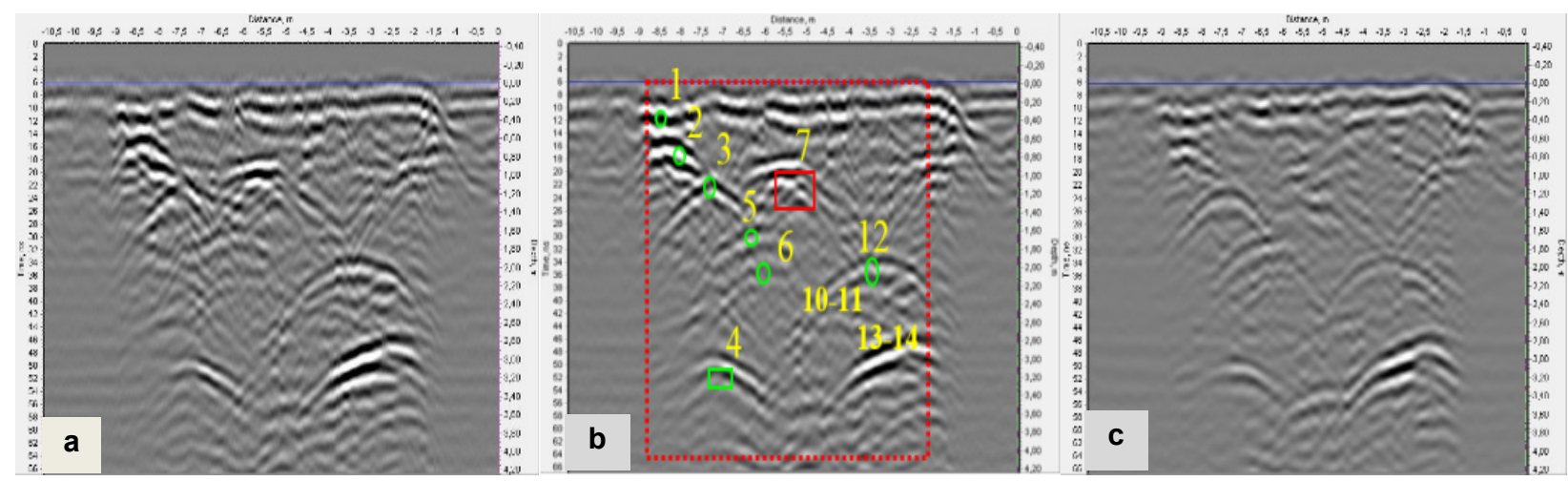

Fig. 5. GPR profiles recorded with VIY3-300 GPR on the spot "Trench"

(direction 3, in the center on the plan on fig. 1a) with depth of sounding $65 \mathrm{~ns}$ or $4.2 \mathrm{~m}$ and with different steps $\Delta x$ on profile: $\mathrm{a}-\Delta x=30,94 \mathrm{~mm} ; \mathrm{b}-\Delta x=123 \mathrm{~mm}$ (numbers for anomalies according to numbers of objects on fig. 1a); $\mathrm{c}-\Delta x=154 \mathrm{~mm}$

distance, in

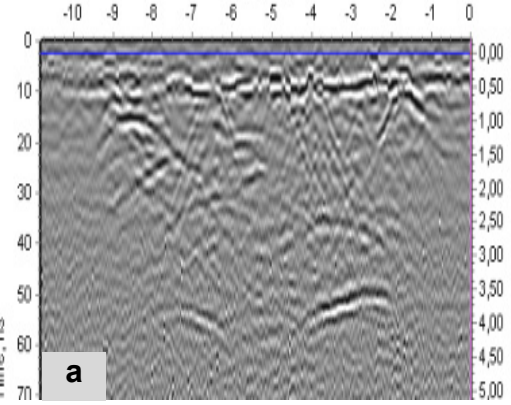

Distance, $\mathrm{m}$

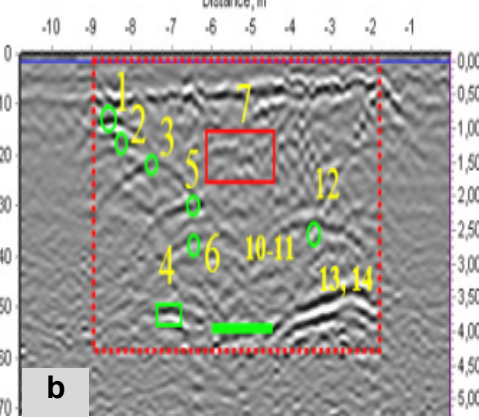

Distance, in

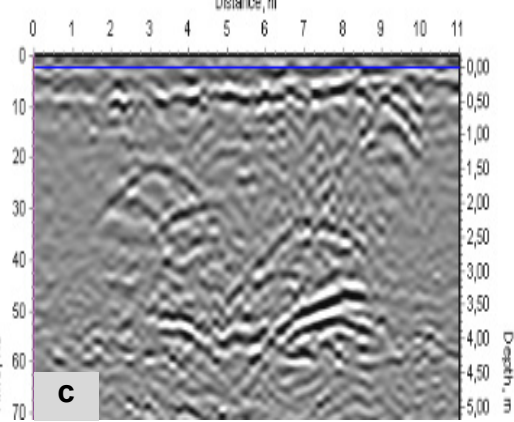

Fig. 6. GPR profiles recorded with VIY3-300 GPR on the spot "Trench"

(direction 3, in the center on the plan on fig. 1a) with depth of sounding $140 \mathrm{~ns}$ or $9.1 \mathrm{~m}$ and with different steps $\Delta x$ on profile: a $-\Delta x=30,94 \mathrm{~mm}, \mathrm{~b}-\Delta x=123 \mathrm{~mm}$ (numbers for anomalies according to numbers for objects on fig. 1a), $c-\Delta x=154 \mathrm{~mm}$

4-point scale was developed to evaluate quality of GPR profiles: 3 points - reflection from object is clear and can be differentiated from other reflections; 2 points reflection is identified, but it is a bit colliding with other reflections; 1 point - exact reflection is hardly differentiated from other reflections; 0 points - refection is invisible on GPR profile. Comparison of profiles with different set- tings and seasons of survey was done according to the total sum of points. Represented scale has not been used before for GPR surveying.

As an example there is a table 2 with points for different profiles, which were recorded on spot "Trench" with VIY2-300 GPR. Similar tables were filled with points for other GPRs and for other seasons of survey.

Evaluation and comparison of the GPR profiles, recorded with VIY2-300 GPR on the spot "Trench"

\begin{tabular}{|c|c|c|c|c|c|c|c|}
\hline \multirow{2}{*}{$\begin{array}{c}\text { Depth of } \\
\text { measurement }\end{array}$} & \multirow{2}{*}{$\begin{array}{c}\text { Step of } \\
\text { measurement, } \mathrm{mm}\end{array}$} & \multicolumn{5}{|c|}{ Number of object, for which the quality of reflection is evaluated } & \multirow{2}{*}{$\begin{array}{l}\text { Total sum } \\
\text { of points }\end{array}$} \\
\hline & & 1 & 2 & 5 & 6 & $10-11$ & \\
\hline \multirow[t]{6}{*}{$67,4.2$} & 30.94 & 3 & 1 & 3 & 2 & 2 & 11 \\
\hline & 61.8 & 3 & 1 & 3 & 3 & 3 & 13 \\
\hline & 92 & 3 & 1 & 3 & 2 & 3 & 12 \\
\hline & 123 & 3 & 2 & 3 & 3 & 2 & 13 \\
\hline & 154 & 3 & 1 & 3 & 2 & 1 & 10 \\
\hline & 216 & 3 & 0 & 3 & 1 & 1 & 8 \\
\hline \multirow[t]{6}{*}{100,7} & 30.94 & 3 & 1 & 3 & 3 & 1 & 11 \\
\hline & 61.8 & 3 & 1 & 3 & 2 & 3 & 12 \\
\hline & 92 & 3 & 1 & 3 & 3 & 3 & 13 \\
\hline & 123 & 3 & 1 & 3 & 3 & 2 & 12 \\
\hline & 154 & 3 & 1 & 3 & 3 & 1 & 11 \\
\hline & 216 & 3 & 0 & 2 & 0 & 1 & 6 \\
\hline \multirow[t]{5}{*}{120,9} & 30.94 & 2 & 1 & 2 & 1 & 0 & 6 \\
\hline & 61.8 & 3 & 1 & 3 & 3 & 3 & 13 \\
\hline & 92 & 3 & 1 & 2 & 2 & 3 & 11 \\
\hline & 123 & 3 & 2 & 3 & 1 & 1 & 10 \\
\hline & 154 & 2 & 0 & 3 & 2 & 2 & 9 \\
\hline \multirow[t]{5}{*}{165,12} & 30.94 & 3 & 1 & 3 & 2 & 2 & 11 \\
\hline & 61.8 & 3 & 1 & 3 & 2 & 2 & 11 \\
\hline & 92 & 3 & 1 & 3 & 2 & 2 & 11 \\
\hline & 123 & 3 & 1 & 1 & 2 & 2 & 9 \\
\hline & 154 & 3 & 1 & 1 & 2 & 2 & 9 \\
\hline
\end{tabular}


As a result of analysis of achieved data on the experimental site, it is concluded that following several recommendations will help to get the most informative results in shortest time:

1. GPR surveying should be done along parallel profiles and distance between them should be minimum 2 times less than parameters of the object of investigation;

2. For 300 and $500 \mathrm{MHz}$ GPR antennas, it is better to follow technical and methodological recommendations, such as:

a) while first-time investigations (regional) it is better to set depth of measurement, which is 1.5-2 times more, than depth to the object, vertical resolution should be 500 points and step of measurement $130-175 \mathrm{~mm}$;

b) for precise (local) investigations number of points on vertical axis should be from 500 to 1000 and step of measurement from 30 to $130 \mathrm{~mm}$; depth of sounding should be on 0.5 to $2 \mathrm{~m}$ deeper than location of objects for $300 \mathrm{MHz}$ antenna and on $0.5 \mathrm{~m}$ deeper for $500 \mathrm{MHz}$ antenna;

3. To increase ration signal/noise on resulting GPR profiles, it is better to:

a) decrease the distance from the device to the surface of investigated environment - to remove snow, wood, rubbish and other obstacles between GPR and surface of investigation;

b) to use devices with (minimal characteristics): analogueto-digital converter range 10,18 bits; dynamic range $100 \mathrm{~dB}$;

4. To get precise depth to the reflections, relative dielectric permittivity of investigated environment should be precisely measured (laboratory investigations of samples, electric well-logging, etc.);

5. To get full understanding of geophysical and geological model of investigated environment, 2-D and 3-D modelling of electromagnetic waves' fields should be done before (prediction of the model) and after (based on the results of the survey) survey.

From the authors' point of view, proposed method of quality evaluation and mentioned recommendations should be taken into consideration while solving real geological and engineering problems with GPR in similar to experimental site's conditions.

Represented method of GPR profiles quality evaluation is not perfect and will be modified for more convenient practical application during GPR surveys. Authors are working on improvement of quality assessment algorithms and techniques for precise measurement of dielectric permittivity in the field.

\section{References:}

1. Vladov, M.L., Starovoytov, A.V. (1999). Georadiolokatcionnye issledovaniya verkhney chasti razreza. Moskow: MGU. [In Russian].

2. Dortman, N.V. (1984). Fizicheskie svoistva gornykh porod i poleznykh iskopaemykh. Spravochnik geofizika. [Physical properties of rocks and ores. Geophysics handbook]. Moskow: Nedra. [In Russian]

3. Petrovskiy, A.D. (1971). Radiovolnovye metody $v$ podzemnoy geofizike. Moskow: Nedra.

4. Finkelshteyn, M.I., Karpukhin, V.I., Kutev, V.A., Metelkin, V.N. (1994). Podpoverkhnostnaya radiolokatsiya. Moskow: Radio i svyaz. [In Russian].

5. Sugak, V.G., Bukin, A.V., Ovchinkin, O.A., Padenko, Y.A., Silaev, Y.S. (2005). Primenenie spetsializirovannogo georadiolokatora $v$ zadachakh inzhenernoy geologii, gidrogeologii i ekologii. Nauka ta innovatsii, 1(2), 3243. [In Russian]

6. Site of Company Transient Technologies LLC. www.viy.ua. Retrieved from http:/www.viy.ua.

7. Finkelshteyn, M.I., Mendelson, M.I., Kutev, V.A. (1977). Radiolokatsiya sloistykh zemnykh pokrovov. Moskow: Sovetskoe radio. [In Russian].

8. Finkelshteyn, M.I., Kutev, V.A., Zolotarov, V.P. (1986). Primenenie podpoverkhnostnogo zondirovaniya $v$ inzhenernoy geologii. Moskow: Nedra. [In Russian].

9. Khaptanov, V.B., Bashkuev, Y.B., Buyanova, D.G. (2013). Rezultaty radioimpedansnogo i georadarnogo zondirovaniy pribrezhnoy zony Srednego Baykala. Vestnik SibGAU, №5(51), 149-152. [In Russian]

10. Chernov, A.P., Goliaka, R.P. (2015). Vyiavlennia neodnoridnostei u verkhnii chastyni heolohichnoho seredovyshcha za dopomohoiu heoradara VIY3-300 [Identifiction of heterogeneity in upper part of geological medium with VIY3-300 GPR]. Proceedings of the Youth scientific conference "Modern directions of researches in Ukraine" (Kyiv, November 25-26, 2015) - Suchasni napriamy heolohichnykh doslidzhen v Ukraini : Zb. mater. molodizhnoi nauk. konf.(25-26 lystopada 2015 r.). (p. 52). Kyiv: Institute of geological sciences Academy of science of Ukraine. [In Ukrainian]
11. Chernov, A.P. (2016). Ohliad problemnykh pytan heoradarnykh doslidzhen [Review of GPR survey issues]. Proceedings of the IVth allUkrainian youth conference-school "Current problems of geological science" (Kyiv, May 14-16 2016) - VI Vseukr. molodizhna nauk. konferentsiia-shkola "Suchasni problemy heolohichnykh nauk" (14-16 maia 2016). Institute of geology, Taras Shevchenko National University of Kyiv. (pp. 161-164). Kyiv: Nika-Tsentr. [In Ukrainian].

12. Shemshurin, V.A. (1962). Metodicheskoe rukovodstvo po radiovolnovomu zondirovaniyu (RVZ) pri razvedke podzemnykh vod $v$ aridnoy zone. Moskow. [In Russian].

13. Yankovskiy, K.P. (2002). Otsenka diagnosticheskikh vozmozhnostey system georadarnogo zondirovaniya prirodnykh i prirodno-antropogennykh obyektov. Candidate's of Sci. (Techn.) thesis. diss.rs1.ru. Moskow. [In Russian].

14. Daniels, D.J. (Eds.). (2004). Ground-penetrating radar. (2nd ed.). London: The Institution of Electrical Engineers, $726 \mathrm{p}$

15. Tomaszewska, E., Kaminska, D., Lukowski, J. (2011). The use of GPR technique to identify objects of anthropogenic origin. Geodynamika Geodynamics, 2(11), 296-297.

16. Yelf, R.J. (2007). Application of Ground Penetrating radar to Civil and Geotechnical Engineering. Electromagnetic Phenomena - Elektromagnitnye lavleniia, 7, 1(18), 103-117. Retrieved from http://emph.com.ua/18/pdf/yelf_01.pdf.

\section{Список використаних джерел:}

1. Владов М. Л. Георадиолокационные исследования верхней части разреза / М. Л. Владов, А. В. Старовойтов. - М.: Изд-во МГУ, 1999. - 91 с.

2. Дортман Н. В. Физические свойства горных пород и полезных ископаемых. Справочник геофизика / Н. В. Дортман. - М.: Недра, 1984. - 485 с.

3. Петровский А. Д. Радиоволновые методы в подземной геофизике / А. Д. Петровский. - М.: Недра, 1971. -223 с.

4. Подповерхностная радиолокация / М. И. Финкельштейн, В. И. Карпухин, В. А. Кутев, В. Н. Метелкин. - М.: Радио и связь, 1994. - 216 с

5. Применение специализированного георадиолокатора в задачах инженерной геологии, гидрогеологии и экологии / В. Г. Сугак, А.В.Букин, О. А. Овчинкин и др. // Наука та інновації. - 2005. - 1, №2. - С. 32-43.

6. Сайт компанії "Transient Technologies LLC" [Электронный ресурс]. Режим доступа : http://www.viy.ua.

7. Финкельштейн М. И. Радиолокация слоистых земных покровов / М. И. Финкельштейн, В. А. Мендельсон, В. А. Кутев. - М.: Советское радио, 1977. - $176 \mathrm{c}$.

8. Финкельштейн М.И.Применение подповерхностного зондирования в инженерной геологиии / М. И. Финкельштейн, В. А. Кутев, В. П. Золотарев. - М.: Недра. - 1986. - 128 с.

9. Хаптанов В. Б. Результаты радиоимпедансного и георадарного зондирований прибрежной зоны Среднего Байкала / В. Б. Хаптанов, Ю. Б. Башкуев, Д. Г. Буянова // Вестник СибГАУ. - 2013 - №5(51) - С. 149-152.

10. Чернов А. П. Виявлення неоднорідностей у верхній частині геологічного середовища за допомогою георадара VIY3-300 / A. П. Чернов, Р. П. Голяка // Сучасні напрями геологічних досліджень в Україні : Зб. матер. молодіжної наук. конф.(25-26 листопада 2015 р.) ; Інститут геологічних наук НАН України. - К., 2015. - С. 52.

11. Чернов А. П. Огляд проблемних питань георадарних досліджень / А. П. Чернов // VI Всеукр. молодіжна наук. конференція-школа "Сучасні проблеми геологічних наук" (14-16 квітня 2016 р.) ; ННІ "Інститут геологіі" Київського Національного університету імені Тараса Шевченка. - К. Ніка-Центр, 2016. - С. 161-164.

12. Шемшурин В. А. Методическое руководство по радиоволновому зондированию (РВ3) при разведке подземных вод в аридной зоне / В. А. Шамшурин. - М., 1962. - 48 с.

13. Янковский К. П. Оценка диагностических возможностей систем георадарного зондирования природных и природно-антропогенных объектов : дис. ... канд. техн. наук / К. П. Янковский. - - М., 2002. - 141 с.

14. Ground-penetrating radar / ed. by D. J. Daniels. - 2nd ed. - London: The Institution of Electrical Engineers, 2004. - 726 p.

15. Tomaszewska E. The use of GPR technique to identify objects of anthropogenic origin / E. Tomaszewska, D. Kaminska, J. Lukowski // 「eoдинаміка. - 2011. - 2(11). - C. 296-297.

16. Yelf R. J. Application of Ground Penetrating radar to Civil and Geotechnical Engineering [Электронный ресурс] / R. J. Yelf // Electromagnetic Phenomena - Электромагнитные Явления. - 2007. - V.7, №1(18). P. 103-117. - Режим доступа : http://emph.com.ua/18/pdf/yelf_01.pdf

надійшла до редколегії 05.09.16 
А. Чернов, магістр, геофізик,

E-mail: achernovp@gmail.com,

М. Рева, канд. фіз.-мат. наук, доц.,

E-mail: mvreva@gmail.com,

Київський національний університет імені Тараса Шевченка,

НHI "Інститут геології", вул. Васильківська, 90, м. Київ, 03022

\section{ІНФОРМАТИВНІСТЬ ГЕОРАДАРНОГО МЕТОДУ ЗА РЕЗУЛЬТАТАМИ ЕКСПЕРИМЕНТАЛЬНИХ ДОСЛІДЖЕНЬ НА НАВЧАЛЬНО-ЕКСПЕРИМЕНТАЛЬНОМУ ПОЛІГОНІ}

У статmі наведено результати георадарних досліджень, виконаних на навчально- експериментальному полігоні НнІ "Інститут геології" Київського національного університету імені Тараса Шевченка (м. Київ). Георадарний метод інтенсивно розвивається з 1970-х років, але питання оцінки якості проведених робіт та визначення найкращих параметрів георадарних зйомок і нині залишаються в колі дискусійних тем. Георадарні дослідження на штучно створеному експериментальному навчальному полігоні проведено трьома георадарами з використанням двох частот антенних блоків - 300 МГи та 500 МГц. Оцінка інформативності методу виконувалася за результатами аналізу отриманих експериментальних даних, основу якого складали такі критерії: відповідність аномалій, зареєстрованих на георадарному профілі, фактичному розташуванню об'єктів дослідження; залежність якості георадарних профілів та їх інформативності від центральної частоти досліджуваної антени й просторової детальності сканування (кроку дослідження по профілю); вплив на якість георадарних профілів тривалості реєстрації георадарних трас ("налаштованої глибинності досліджень") та детальності їх часової дискретизації (кількості точок по вертикалі); вплив на якість георадарних досліджень часового періоду виконання експериментальних вимірів. Порівняльний аналіз результатів георадарних досліджень виконано на основі авторської методики оцінки їхньої якості. У результаті проведеного аналізу експериментальних даних сформульовано висновки та надано практичні рекомендації, які бажано використовувати при георадарних дослідженнях на територіях, подібних за геологією та характеристиками розташованих на них об'єктів до ділянок навчально-експериментального полігону.

Ключові слова: георадар, георадіолокація, георадарний профіль, діелектрична проникність, питомий електричний опір, сигнал зондування, електромагнітний імпульс, швидкість хвилі.

А. Чернов, магистр геофизики

E-mail: achernovp@gmail.com,

Н. Рева, канд. физ.-мат. наук, доц.

E-mail: mvreva@gmail.com,

Киевский национальный университет имени Тараса Шевченко,

УнИ "Институт геологии", ул. Васильковская, 90, г. Киев, 03022

\section{ИНФОРМАТИВНОСТЬ ГЕОРАДАРНОГО МЕТОДА ПО РЕЗУЛЬТАТАМ ЭКСПЕРИМЕНТАЛЬНЫХ ИССЛЕДОВАНИЙ НА УЧЕБНО-ЭКСПЕРИМЕНТАЛЬНОМ ПОЛИГОНЕ}

В статье представлены результаты георадарных исследований, выполненных на учебно-экспериментальном полигоне УнИ "Институт геологии" Киевского национального университета имени Тараса Шевченко (е. Киев, Украина). Георадарный метод интенсивно развивается с 1970-х годов, но вопросы оценки качества проводимых работ и определения наилучших параметров георадарных съемок и сейчас остаются в кругу дискуссионных тем. Георадарные исследования на искусственно созданном учебноэкспериментальном полигоне проведены тремя георадарами с использованием двух частот антенных блоков - 300 МГи и 500 МГц. Оценка информативности метода выполнялась по результатам анализа полученных экспериментальных данных, основу которого составляли следующие критерии: соответствие аномалий, зарегистрированных на георадарном профиле, фактическому расположению объектов исследования; зависимость качества георадарных профилей и их информативности от иентральной частоть антенного блока и пространственной детальности сканирования ("шага исследования по профилю"); влияние на качество георадарных профилей длительности регистрации георадарных трасс ("настроенной глубинности исследований") и детальности их временной дискретизации ("количества точек по вертикали"); влияние на качество георадарных исследований временного периода выполнения экспериментальных измерений. Сравнительный анализ результатов георадарных исследований выполнен на основе авторской методики оценки их качества. В результате проведенного анализа экспериментальных данных сформулированы выводы и даны практические рекомендации, которые желательно использовать при георадарных исследованиях на территориях, подобных по геологии и характеристикам расположенных на них объектов участкам учебно-экспериментального полигона.

Ключевые слова: георадар, георадиолокация, георадарый профиль, диэлектрическая проницаемость, удельное электрическое сопротивление, сигнал зондирования, электромагнитный импульс, скорость волны. 